\title{
UPSUS PAJALE DALAM MENUNJANG PROGRAM SWASEMBADA PANGAN DI KABUPATEN BOLAANG MONGONDOW
}

\author{
Jeremy Ponto \\ Noortje M. Benu \\ Ribka M. Kumaat
}

\begin{abstract}
This study aims to determine the trend of agricultural production in supporting food self-sufficiency program "PAJALE" in Bolaang Mongondow District. This research conducted for 3 months. The data used in this research is secondary data obtained from Agriculture Department of North Sulawesi Province. The variables that will be measured in this research are (1). Rice production Year 2015 - 2016, (2). Corn production Year 2015 - 2016, (3). Soybean Production Year 2015 - 2016. The analysis used in this research is descriptive analysis using time series data. In conclusion, the production of rice, corn and soybean crops in 2015 is ATAP 2015 data. The research shows that there is an increase in rice production, corn, soybean in Bolaang Mongondow in 2015 - 2016, due to the presence of UPSUS in the form of 2015 until 2017.
\end{abstract}

Keywords: UPSUS pajale, food self-sufficiency program, Bolaang Mongondow District

\begin{abstract}
ABSTRAK
Penelitian ini bertujuan untuk mengetahui trend produksi pertanian dalam menunjang program swasembada pangan "PAJALE" di Kabupaten Bolaang Mongondow. Penelitian ini dilaksanakan selama 3 bulan. Data yang digunakan dalam penelitian ini yaitu data sekunder yang diperoleh dari Dinas Pertanian Provinsi Sulawesi Utara. Variabel yang akan diukur dalam penelitian ini yaitu (1). Produksi Padi Tahun 2015 - 2016, (2). Produksi Jagung Tahun 2015 - 2016, (3). Produksi Kedelai Tahun 2015 - 2016. Analisis yang digunakan dalam penelitian ini adalah analisis deskriptif dengan menggunakan data time series. Kesimpulan, produksi hasil panen padi, jagung dan kedelai pada tahun 2015 adalah data ATAP 2015. Terjadi kenaikan produksi padi, jagung, kedelai di Bolaang Mongondow tahun 2015 - 2016, karena adanya UPSUS yang di bentuk tahun 2015 sampai tahun 2017.
\end{abstract}

Kata kunci: UPSUS pajale, program swasembada pangan, Kabupaten Bolaang Mongondow 


\section{PENDAHULUAN}

\section{Latar Belakang}

Tanaman pangan merupakan sektor penting, karena tanaman pangan merupakan kelompok tanaman yang menghasilkan bahan pangan sebagai sumber energi untuk menopang kehidupan manusia. Terdapat banyak jenis karbohidrat sebagai salah satu sumber bahan pangan di seluruh dunia baik itu terdiri dari serelia maupun umbi - umbian. Indonesia sendiri saat ini memprioritaskan empat jenis tanaman pangan di indonesia yaitu padi, jagung, kedelai, dan ubi kayu. Ketersediaan tanaman pangan sangat penting kiranya untuk memenuhi kebutuhan pangan bagi masyarakat secara berkelanjutan. Upaya pemerintah dalam meningkatkan pertanian pangan dapat dilihat dari program yang dilakukan seperti Upaya Khusus (Upsus) dalam peningkatan produksi pangan yang terfokus di tiga komoditas utama yaitu Padi, Jagung, Kedelai (Pajale), Pengelolaan Tanaman Terpadu atau PTT padi sawah bertujuan untuk meningkatkan produktivitas tanaman dari segi hasil dan kualitas melalui penerapan teknologi yang sesuai dengan spesifik lokasi serta program lainnya. Padi jagung dan kedelai merupakan komoditas strategis yang unik di Indonesia. Peran kedelai sangat penting dalam menu pangan penduduk. Sejak dahulu, kedelai telah dikenal sebagai sumber protein nabati bagi penduduk Indonesia (Supadi, 2009).

Pajale adalah akronim dari padi, jagung, dan kedelai yang mana saat ini sedang maraknya program pemerintah untuk meningkatkan produksi ketiganya guna pencapaian swasembada pangan berkelanjutan. Swasembada pangan adalah keadaan dimana suatu negara mampu memenuhi kebutuhannya sendiri dalam bidang pangan. Sebagai upaya untuk memenuhi kebutuhan pangan yang terus meningkat, pemerintah telah menetapkan Pencapaian Swasembada Pangan Berkelanjutan yang harus dicapai dalam waktu 3 (tiga) tahun. Upaya peningkatan produksi padi, jagung dan kedelai terus digulirkan pemerintah pusat. Dana dalam jumlah besar dari Anggaran Pembangunan Belanja Negara Perubahan (APBN) 2015 sebesar Rp 16,9 triliun. Dengan dana sebesar itu pemerintah memberikan sejumlah target penambahan produksi padi, jagung dan kedelai bagi setiap daerah. Rencananya, dengan berbagai bantuan itu petani bisa meningkatkan produktivitas dan menambah areal tanamnya. Bantuan tersebut kemudian disampaikan kepada para petani dalam bentuk bantuan benih, pupuk, perbaikan irigasi, alat dan mesin pertanian. Maka program UPSUS pemerintah merupakan tombak awal swasembada pangan di Indonesia. Komoditi padi, jagung, dan kedelai sebagai komoditi utama yang harus diupayakan mampu untuk memenuhi kebutuhan hidup masyarakat.. Maka dari itu perlunya dilakukan penelitian mengenai trend produksi pertanian dalam menunjang program swasembada pangan PAJALE di Kabupaten Bolaang Mongondow.

\section{Rumusan Masalah}

Bagaimana trend produksi pertanian dalam menunjang program swasembada pangan "PAJALE" di Kabupaten Bolaang Mongondow

\section{Tujuan}

Penelitian ini bertujuan untuk mengetahui trend produksi pertanian dalam menunjang program swasembada pangan "PAJALE" di Kabupaten Bolaang Mongondow.

\section{Manfaat Penelitian}

Manfaat penelitian ini untuk mengetahui besarnya peran tanaman pangan $b$ dalam upaya khusus "PAJALE" di Kabupaten Bolaang Mongondow.

\section{METODOLOGI PENELITIAN}

\section{Waktu dan Tempat}

Penelitian ini dilaksanakan selama 1 tahun yaitu tahun 2016 - tahun 2017. Lokasi penelitian yaitu di Dinas Pertanian Provinsi Sulawesi Utara.

\section{Jenis dan Sumber Data}

Data yang digunakan dalam penelitian ini yaitu data sekunder yang diperoleh dari Dinas Pertanian Provinsi Sulawesi Utara

\section{Konsep Pengukuran Variabel}

Variabel yang akan diukur dalam penelitian ini yaitu: 
1. Produksi Padi Tahun 2015 - 2016

2. Produksi Jagung Tahun 2015 - 2016

3. Produksi Kedelai Tahun 2015 - 2016

\section{Analisis Data}

Analisis yang digunakan dalam penelitian ini adalah analisis deskriptif dengan menggunakan data time series.

\section{HASIL DAN PEMBAHASAN}

\section{Letak Dan Luas Wilayah}

Penelitian ini dilakukan di Kabupaten Bolaang Mongondow. Kabupaten Bolaang Mongondow secara administrative terbagi kedalam 15 kecamatan dan 200 desa/kelurahan. Luas keseluruhannya mencapai $3.506,24 \mathrm{~km}^{2}$. Kabupaten Bolaang Mongondow merupakan salah satu Kabupaten yang terletak di provinsi Sulawesi Utara dan memiliki batas - batas : Utara - Laut sulawesi; Selatan - Kabupaten Bolaang Mongondow Selatan dan Kabupaten Bolaang Mongondow Timur; Barat Kabupaten Bolaang Mongondow Utara; dan Timur - Kabupaten Minahasa Selatan dan Kabupaten Minahasa Tenggara. Kabupaten Bolaang Mongondow adalah salah satu kabupaten yang terletak di Provinsi Sulawesi Utara. Ibu Kota Kabupaten Bolaang Mongondow adalah Lolak. Kabupaten Bolaang Mongondow memiliki etnis mayoritas yaitu suku Mongondow dengan bahasa penduduk aslinya yaitu bahasa Mongondow. Kabupaten Bolaang Mongondow ditetapkan pada tanggal 23 maret 1954, terletak pada salah satu daerah Sulwesi Utara yang secara historis adalah bekas danau. Kabupaten ini merupakan daerah subur dengan hasil utama tambang dan hasil bumi lainnya. Wilayah Kabupaten Bolaang Mongondow telah mengalami sejumlah pemekaran. Tahun 2007 dimekarkan menjadi Kota Kotamobagu dan Kabupetan Bolaang Mongondow Utara. Pada tahun 2008 dimekarkan lagi menjadi Kabupaten Bolaang Mongondow Timur dan Kabupaten Bolaang Mongondow Selatan.

\begin{tabular}{llr}
\multicolumn{3}{c}{ Keadaan Penduduk } \\
Penduduk & Kabupaten & Bolaang \\
Mongondow pada tahun 2015 & sebanyak \\
233.189. Meningkat 3.585 dari tahun 2014 dan
\end{tabular}

18.890 dari tahun 2010. Selama periode 20102015, rata-rata pertumbuhan penduduk tiap tahun sebesar 1,505 persen. Sedangkan pertumbuhan penduduk tiap tahun pada periode 2014-2015 sebesar 1,348 persen. Tingkat kepadatan penduduk Kabupaten Bolaang Mongondow di tahun 2014 mencapai 64,00 jiwa $/ \mathrm{km}^{2}$. Passi Barat masih menjadi kecamatan dengan tingkat kepadatan tertinggi, yaitu mencapai 165,95 jiwa $/ \mathrm{km}^{2}$, sedangkan tingkat kepadatan terendah adalah kecamatan Sang Tombolang, yaitu hanya $13,19 \mathrm{jiwa} / \mathrm{km}^{2}$. Rasio jenis kelamin Kabupaten Bolaang Mongondow pada tahun 2014 masih di atas 100, yaitu mencapai 108,35, yang berarti jumlah penduduk laki - laki masih lebih banyak dari jumlah penduduk perempuan. Sebagian besar penduduk Kabupaten Bolaang Mongondow memeluk agama Islam yaitu $61 \%$ dan sisanya Kristen 33 $\%$, Hindu 5\% serta Katolik 1\%.

\section{PAJALE di Bolaang Mongondow}

Adanya upaya khusus padi (UPSUS) padi, jagung, dan kedelai yang melibatkan TNI dalam mengawal dan memantau pelaksanaan tanam dan panen padi, jagung, dan kedelai sehingga kelompok tani dapat mempercepat penanaman dan panen tepat waktu. Terlaksananya pemberian bantuan sarana produksi berupa benih dan pupuk. Upaya peningkatan padi, jagung, dan kedelai baik dari kuantitas maupun kualitas terus diupayakan oleh pemerintah. Pengembangan komoditas kedelai untuk dijadikan unggulan sub sektor tanaman pangan perlu mendapat dukungan dari semua pihak terkait berkaitan dengan adanya program PAJALE yang dicanangkan pemerintah.

\section{Padi}

Pada tabel berikut ini dapat di lihat perkembangan produksi padi ( 3 kali produksi) dalam 2 tahun 2015 - 2016.

Tabel 1. Produksi Padi Kabupaten Bolaang Mongondow 2015

\begin{tabular}{ccc}
\hline Periode & Bulan & Produksi (Ton) \\
\hline I & Januari - April & 81545 \\
\hline II & Mei - Agustus & 112787 \\
\hline III & $\begin{array}{c}\text { September - } \\
\text { Desember }\end{array}$ & 118167 \\
& Total & 312499 \\
\hline \multirow{2}{*}{$\begin{array}{c}\text { Sumber : Badan Pusat Statistik Provinsi Sulawesi } \\
\text { Utara }\end{array}$}
\end{tabular}


Gambar 1 menunjukan total produksi tanaman padi pada tahun 2015 yang sebanyak 312.499 ton. Periode januari - april sebesar 81545 luas panen 18420 ha, periode Mei - Agustus sebesar 112787 ton luas panen 22200 ha. Pada periode berikut mengalami kenaikan produksi sebanyak 118167 ton luas panen 22731 ha. Sesuai data yg ada tardapat kenaikan secara bertahap pada setiap periode panen. Angka yang dipakai dalam trend produksi padi (sawah + ladang)

Tahun 2015 adalah angka tetap 2015 sulawesi utara. Faktor yang sangat mempengaruhi produksi panen ditahun 2015 adalah hasil panen periode sebelumnnya dipanen pada periode selanjutnya begitu seterusnya. Selain faktor periode panen ada banyak faktor yang mempengaruhi produksi panen padi pada tahun 2015 seperti faktor-faktor luas lahan garapan, jumlah tenaga kerja efektif, jumlah pupuk, jumlah pestisida, pengalaman petani dalam berusahatani, jarak rumah petani dengan lahan garapan, dan sistem irigasi berpengaruh sangat nyata terhadap peningkatan produksi padi sawah.

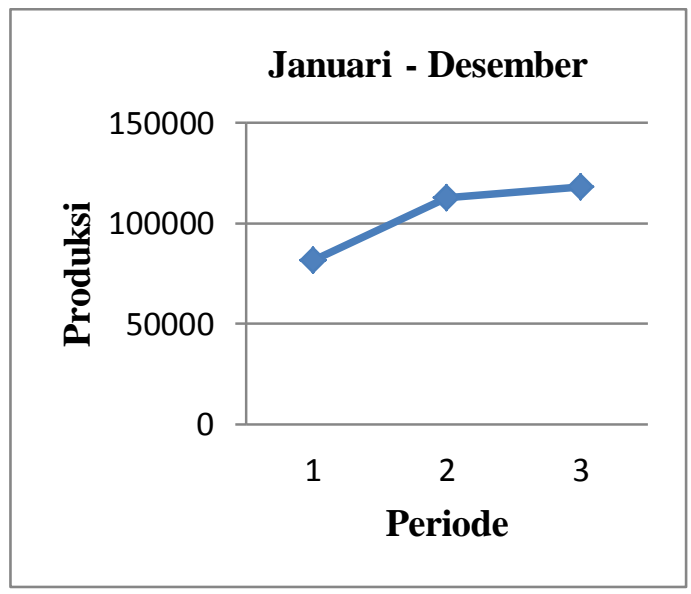

Gambar 1. Trend Produksi Padi Bolaang Mongondow 2015

Tabel 2. Produksi Padi Kabupaten Bolaang Mongondow 2016

\begin{tabular}{ccc}
\hline Periode & Bulan & Produksi (Ton) \\
\hline I & Januari - April & 129633 \\
\hline II & Mei - Agustus & 110599 \\
\hline III & $\begin{array}{c}\text { September - } \\
\text { Desember }\end{array}$ & 120369 \\
\hline & Total & 360601 \\
\hline
\end{tabular}

Sumber : Dinas Pertanian Provinsi Sulawesi Utara

Gambar 2 menunjukkan bahwa total produksi pada tahun 2016 mengalami kenaikan produksi menjadi 360.601 ton dari tahun sebelumnya. Dari periode pertama di tahun 2016 terjadi kenaikan pada periode januari - april
129633 ton luas panen 25926 ha. Pada periode kedua mei - agustus yaitu 110599 ton luas panen 22119 ha. Terjadi kenaikan produksi pada periode September - Desember menjadi 120369 ton luas panen 24073 ha.

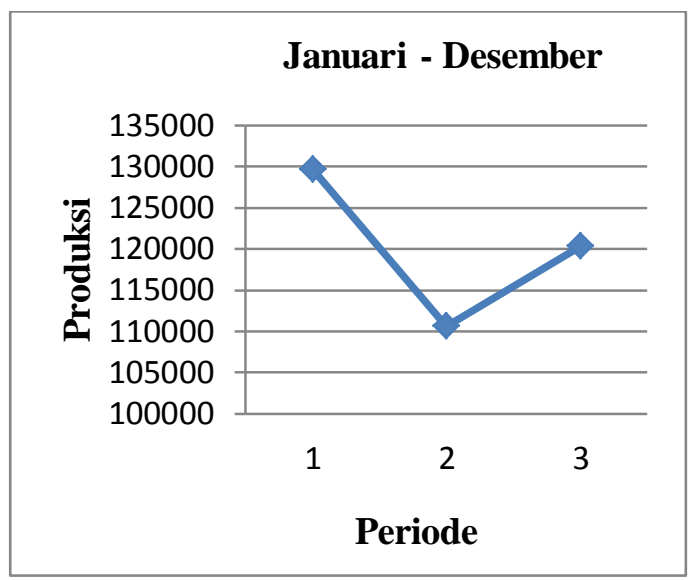

Gambar 2. Trend Produksi Padi Bolaang Mongondow 2016

Kenaikan produksi panen padi di tahun 2016 cenderung turun dibandingkan tahun 2015. Kenaikan produksi tersebut karena hasil per hektar mengalami peningkatan dan juga luas panen yang bertambah ditambah menggunakan teknologi pemupuk yang baik, penggunaan alat mesin pertanian (alsintan), dan juga pupuk yang baik. Beras sebagai makanan pokok masyarakat Indonesia yang merupakan hasil olahan tanaman padi, diupayakan oleh pemerintah agar selalu menjadi tanaman yang selalu diutamakan.hasil produksinya.

\section{Jagung}

Pada tabel di bawah ini dapat di lihat perkembangan produksi jagung ( 3 kali produksi) dalam 2 tahun 2015 - 2016.

Tabel 3. Produksi Jagung Kabupaten Bolaang Mongondow 2015

\begin{tabular}{ccc}
\hline Periode & Bulan & Produksi (Ton) \\
\hline I & Januari - April & 53719 \\
\hline II & Mei - Agustus & 62641 \\
\hline III & September - Desember & 24110 \\
\hline & Total & 140470
\end{tabular}

Sumber: Badan Pusat Statistik Sulawesi Utara

Gambar 3 menunjukkan produksi jagung tahun 2015 yang sebesar 140.470 ton. Pada periode Januari - April sebesar 53719 ton luas panen 14.404 ha, periode Mei Agustus mengalami kenaikan produksi 
sebesar 62.641 ton luas panen 17202 ha. Namun pada periode September - Desember mengalami penurunan produksi menjadi 24.110 ton luas panen 6788 ha.

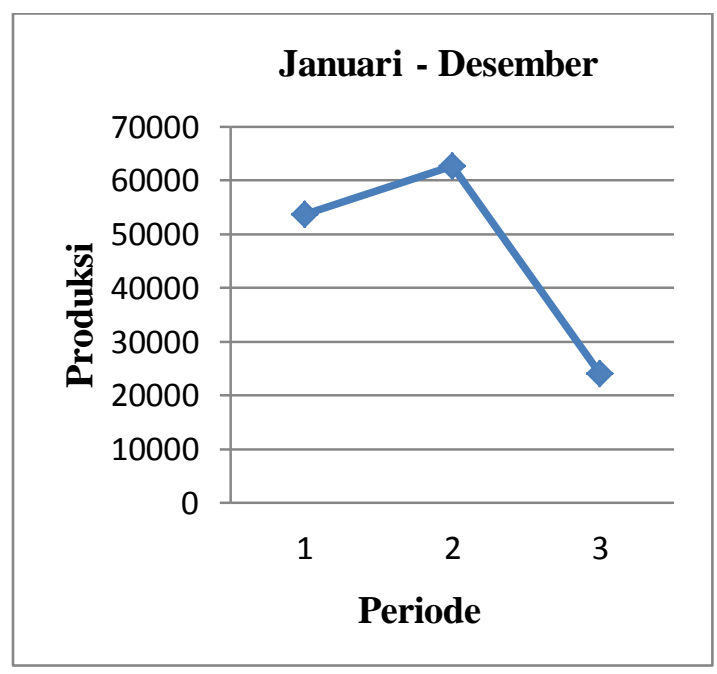

Gambar 3. Trend Produksi Jagung Bolaang Mongondow 2015

Angka yang dipakai dalam trend produksi jagung tahun 2015 adalah angka tetap 2015 yang diambil di Badan Pusat Statistik (BPS) Manado. Di karenakan terlambatnya bantuan pemerintah untuk memberikan bibit unggul sehingga petani hanya menggunakan bibit lokal saja, begitupula hasil produksi panen yang mengalami penurunan. Faktor-faktor yang mempengaruhi produksi dibedakan menjadi 2 kelompok (Soekartawi, 1990), antara lain: (1) Faktor biologi, seperti lahan pertanian dengan macam dan tingkat kesuburannya, bibit, varietas, pupuk, obat-obatan, gulma, dan sebagainya; (2) Faktor sosial ekonomi, seperti biaya produksi, harga, tenaga kerja, tingkat pendidikan, tingkat pendapatan, resiko, dan ketidakpastian, kelembagaan, tersedianya kredit dan sebagainya. Faktor-faktor diatas mempengaruhi hasil produksi tanaman yang mengakiatkan naik turunnya produksi pada periode panen dapat dilihat pada Tabel 4 .

Tabel 4. Produksi Jagung Kabupaten Bolaang Mongondow 2016

\begin{tabular}{ccc}
\hline Periode & Bulan & Produksi (Ton) \\
\hline I & Januari - April & 55390 \\
\hline II & Mei - Agustus & 71324 \\
\hline III & September - Desember & 47341 \\
\hline & Total & 174055
\end{tabular}

Sumber: Dinas Pertanian Provinsi Sulawesi Utara
Gambar 4 menunjukkan produksi jagung pada tahun 2016 periode Januari - April sebanyak 55390 ton luas panen 14677 ha, periode Mei - Agustus 71324 ton luas panen 18899 ha, dan periode September - Desember 47341 ton luas panen 12544 ha.

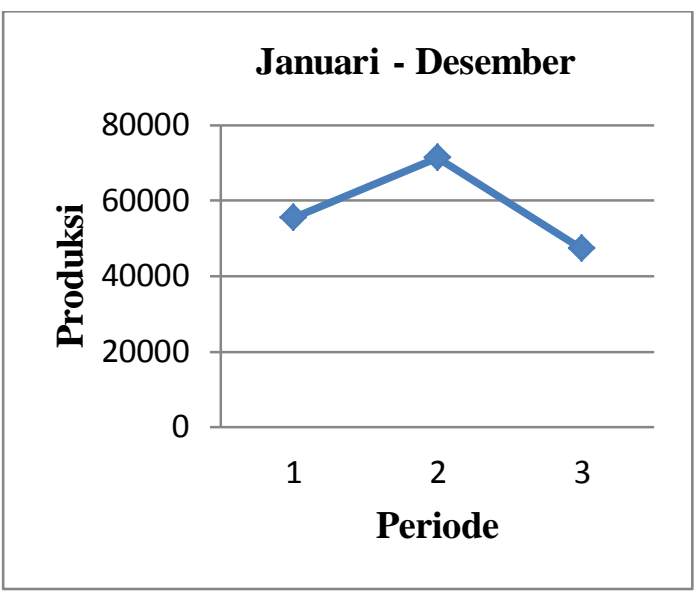

Gambar 4. Trend Produksi Jagung Bolaang Mongondow 2016

Gambar 4 menjelaskan bahwa produksi jagung di tahun 2016 mengalami penurunan dibandingkan tahun 2015. Angka yang dipakai dalam trend produksi jagung tahun 2016 adalah angka tetap 2016 Badan Pusat Statistik (BPS).

\section{Kedelai}

Pada tabel di bawah ini dapat di lihat perkembangan produksi kedelai ( 3 kali produksi) dalam 2 tahun 2015 - 2016 dapat dilihat pada Tabel 5 .

Tabel 5. Produksi Kedelai Bolaang Mongondow 2015

\begin{tabular}{ccc}
\hline Periode & Bulan & Produksi (Ton) \\
\hline I & Januari - April & 1127 \\
\hline II & Mei - Agustus & 1749 \\
\hline III & September - Desember & 551 \\
\hline & Total & 3427
\end{tabular}

Sumber : Badan Pusat Statistik Sulawesi Utara

Gambar 5 menunjukkan produksi kedelai pada periode januari - april sebanyak 1127 ton dengan luas panen 868 ha, pada periode berikut mengalami kenaikan sebanyak 1749 ton yang diikuti dengan bertambahnya luas lahan panen sebesar 1356 ha, namun pada periode berikut mengalami penurunan produksi menjadi 551 ton yang 
diakibatkan karena penurunan luas panen seluas 489 hektar.

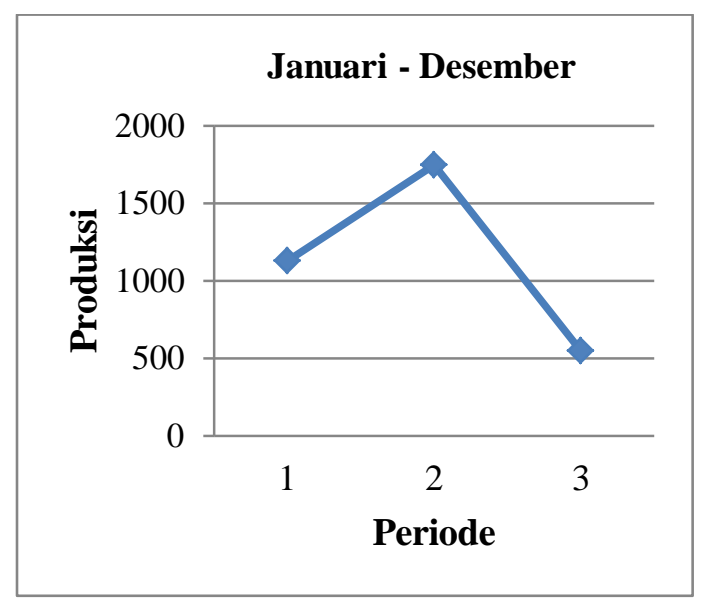

Gambar 5. Trend Produksi Kedelai Bolaang Mongondow 2015

Angka yang dipakai dalam trend produksi kedelai tahun 2015 adalah angka tetap 2015 yang diambil di Badan Pusat Statistik (BPS) Manado.

Tabel 6. Produksi Kedelai Bolaang Mongondow 2016

\begin{tabular}{ccc}
\hline Periode & Bulan & Produksi (Ton) \\
\hline I & Januari - April & 2753 \\
\hline II & Mei - Agustus & 17794 \\
\hline III & $\begin{array}{c}\text { September }- \\
\text { Desember }\end{array}$ & 22415 \\
\hline & Total & 42962 \\
\hline
\end{tabular}

Sumber: Dinas Pertanian Sulawesi Utara 2016

Trend di bawah menunjukkan kenaikan produksi lebih besar pada tahun sebelumnya. Pada periode januari - april sebanyak 2753 ton dengan luas panen 208 ha, pada periode berikut mengalami kenaikan produksi yaitu mei - agustus sebanyak 17794 ton dengan luas panen 1344 ha, dan periode terakhir yaitu September -Desember mengalami kenaikan produksi sebanyak 22415 ton dan luas panen 1693 ha.

Upaya khusus pemerintah dalam mencapai swasembada pangan khususnya di Bolaang Mongondow dibuat Program Gerakan Peningkatan Produksi Tanaman Terpadu (GPPTT) juga penyaluran benih, pupuk, dan alsintan, juga mengawal gerakan perbaikan jaringan irigasi, sistem tanam serentak, dan pengendalian OPT (Organisme
Pengganggu Tanaman). UPSUS pun juga berperan dalam mempercepat penerapan teknologi peningkatan produksi padi, jagung, dan kedelai melalui, dan optimasi lahan di tahun 2015.

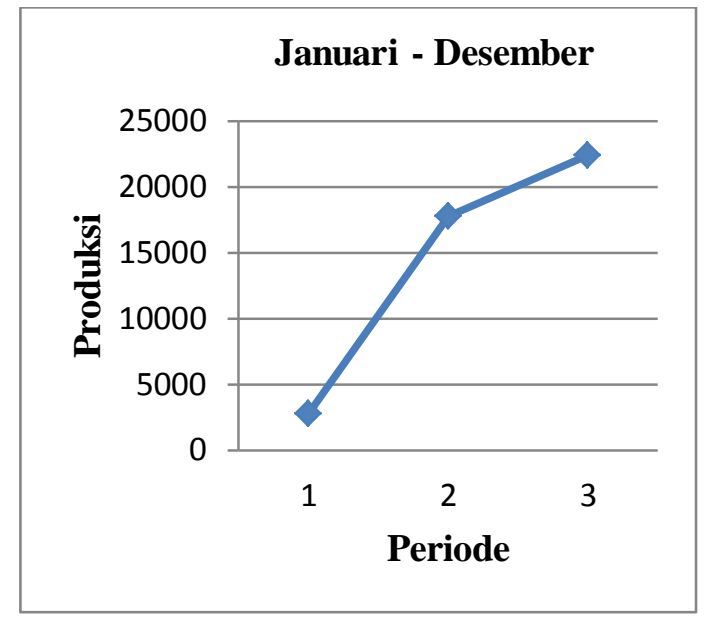

Gambar 6. Trend Produksi Kedelai Bolaang Mongondow 2016

Upaya khusus pemerintah dalam pencapaian swasembada pangan di Indonesia terealisasi dengan baik sebagai bukti, berdasarkan data statistic Badan Pusat Statistik (BPS) Sulawesi Utara. Menurut Berita Resmi Statistik Badan Pusat Statistik No. 44/07/71/Th. XVI, 1 Juli 2016, angka tetap (ATAP) produksi padi tahun 2015 mencapai 674.169 ton Gabah Kering Giling (GKG). Dibandingkan tahun 2014 terjadi peningkatan produksi sebanyak 36.242 ton $(5,68 \%)$. Peningkatan produksi terjadi karena peningkatan luas panen seluas 7.010 hektar $(5,57 \%)$. Angka Tetap produksi jagung tahun 2015 sebesar 300.490 ton pipilan kering. Dibandingkan tahun 2014, terjadi penurunan produksi sebesar 187.872 ton $(-38,47 \%)$, penurunan produksi terjadi karena menurunnya jumlah luas panen seluas 46.590 hektar (-36,55 \%). Angka Tetap produksi kedelai tahun 2015 sebesar 6,685 ton biji kering. Dibandingkan tahun 2014, terjadi penurunan produksi sebesar 844 ton $(-11,21$ $\%)$. Penurunan produksi terjadi karena menurunnya jumlah luas panen seluas 524 hektar $(-9,29 \%)$. Data BPS Provinsi Sulawesi Utara telah menyimpulkan bahwa produksi 
padi Kabupaten Bolaang Mongondow naik dari tahun 2014 - 2015, sesuai dengan data BPS Provinsi Sulawesi Utara tahun 2015. Tetapi produksi jagung kedelai Kabupaten Bolaang Mongondow naik 2015, tidak sesuai dengan data BPS Provinsi Sulawesi Utara yang naik pada tahun 2015. Diketahui bahwa fakta naiknya produksi padi di Kabupaten Bolaang Mongondow 2015 sesuai dengan adanya Upaya Khusus (UPSUS) swasembada PAJALE, tetapi Upaya Khusus tersebut tidak secara menyeluruh menyebar ke seluruh daerah pelosok Provinsi Sulawesi Utara.

\section{KESIMPULAN DAN SARAN}

\section{Kesimpulan}

Produksi hasil panen padi, jagung dan kedelai pada tahun 2015 adalah data ATAP 2015. Terjadi kenaikan produksi padi, jagung, kedelai di Bolaang Mongondow tahun 2015 - 2016, karena adanya UPSUS yang di bentuk tahun 2015 sampai tahun 2017.

Saran
Adanya UPSUS
memberikan dorongan positif pada para
petani Indonesia, untuk mendukung
swasembada pangan. Perlu diperhatikan
untuk bantuan UPSUS harus menyebar secara
menyeluruh, agar swasembada pangan dapat
sukses.

\section{DAFTAR PUSTAKA}

Basu Swastha,. dan Ibnu Sukotjo.1998. Bisnis Pengantar Modern. Yogyakarta: Liberty.

Berita Resmi Statistik Badan Pusat Statistik No. 44/07/71/Th. XVI, 1 Juli 2016.

Bolaang Mongondow Dalam Angka Bolaang Mongondow In Figures. 2015. Badan Pusat Statistik Bolaang Mongondow.
Daniel, M., 2002. Pengantar Ekonomi Pertanian. Bumi Askara. Jakarta.

Husein Umar. 1999. Metode Riset Bisnis. PT Gramedia Pustaka Utama. Jakarta.

Pracoyo, A. 2006. Aspek Dasar Ekonomi Mikro. PT. Gramedia Widiasarana Indonesia. Jakarta.

Pracoyo, A. dan Tri Kunawangsih Pracoyo. 2006. Aspek Dasar Ekonomi Mikro. PT. Grasindo. Jakarta.

Prawiro, Radius. 1998. Pemberdayaan Birokrasi dalam Pembangunan Volume 3. Pustaka Sinar Harapan:Jakarta.

Rukmana, R. 1997. Kacang Hijau Budidaya dan Pasca Panen. Kanisius, Yogyakarta.

Soekartawi. 1990. Teori Ekonomi Produksi, dengan pokok Bahasan Analisis Fungsi Cobb-Douglas. Rajawali Pers, Jakarta.

Soekartawi. 2002. Analisis Usahatani. UI Press. Jakarta.

Sukirno, Sadono. 2002. Teori Mikro Ekonomi. Cetakan Keempat Belas. Rajawali Press: Jakarta.

Sukirno, S., 2003. Pengantar Teori Mikroekonomi. Edisi Ketiga. PT Raja Grafindo Persada. Jakarta.

Sulawesi Utara Dalam Angka, Sulawesi Utara In Figures. 2015. Badan Pusat Statistik Provinsi Sulawesi Utara 
Supriyono, 1994. Akuntansi Biaya dan Akuntansi Manajemen untuk teknologi maju dan globalisasi, ed pertama, Yogyakarta: BPFE.

Supadi. 2009. Dampak Impor Kedelai Berkelanjutan terhadap Ketahanan Pangan. Pusat Analisis Sosial Ekonomi dan Kebijakan Pertanian.
Warsino. 2007. Jagung Hibrida. Kanisius. Yogyakarta.

Wirawan, G.N. dan M.I. Wahab. 2007. Teknologi Budidaya Jagung. 